\title{
CYP3A4 Gene Is a Novel Biomarker for Predicting a Poor Prognosis in Hepatocellular Carcinoma
}

\author{
RYO ASHIDA ${ }^{1,2}$, YUKIYASU OKAMURA ${ }^{1}$, KEIICHI OHSHIMA $^{3}$, YUKO KAKUDA ${ }^{4}$, \\ KATSUHIKO UESAKA ${ }^{1}$, TEIICHI SUGIURA ${ }^{1}$, TAKAAKI ITO ${ }^{1}$, YUSUKE YAMAMOTO ${ }^{1}$, \\ TAKASHI SUGINO ${ }^{4}$, KENICHI URAKAMI ${ }^{5}$, MASATOSHI KUSUHARA ${ }^{6}$ and KEN YAMAGUCHI ${ }^{7}$ \\ ${ }^{1}$ Division of Hepato-Biliary-Pancreatic Surgery, Shizuoka Cancer Center, Shizuoka, Japan; \\ ${ }^{2}$ Department of Surgery, Keio University School of Medicine, Tokyo, Japan; \\ ${ }^{3}$ Medical Genetics Division, Shizuoka Cancer Center Research Institute, Shizuoka, Japan; \\ ${ }^{4}$ Division of Pathology, Shizuoka Cancer Center, Shizuoka, Japan; \\ ${ }^{5}$ Cancer Diagnostics Research Division, ${ }^{6}$ Regional Resources Division, \\ Shizuoka Cancer Center Research Institute, Shizuoka, Japan; \\ ${ }^{7}$ Shizuoka Cancer Center Hospital and Research Institute, Shizuoka, Japan
}

\begin{abstract}
Background/Aim: Project HOPE (High-tech Omics-based Patient Evaluation) began in 2014 using integrated gene expression profiling (GEP) of cancer tissues as well as diathesis of each patient who underwent operation at our Institution. The aim of this study was to identify novel genes displaying altered gene expression related to the survival and early recurrence after hepatectomy for hepatocellular carcinoma (HCC) using the results of integrated GEP analysis. Materials and Methods: The present study included 92 patients. Genes with aberrant expression were selected by the difference of expression levels with $\geq 10$-fold change between tumor and non-tumor tissues. Results. GEP analysis showed that down-regulation was frequently observed in the PRSS8 (64\%), CYP3A4 (61\%) and EPCAM (57\%) genes. Multivariate analysis revealed tumor stage $\geq I I(p=0.008)$ and down-regulation of the CYP3A4 gene $(p=0.036)$ as independent predictor for overall survival. Furthermore, multivariate analysis identified maximum tumor diameter $\geq 74 \mathrm{~mm}(p=0.008)$, presence of intrahepatic-metastasis $(p=0.020)$, and down-
\end{abstract}

This article is freely accessible online.

Correspondence to: Yukiyasu Okamura, MD, Ph.D., Division of Hepato-Biliary-Pancreatic Surgery, Shizuoka Cancer Center, 1007, Shimo-Nagakubo, Sunto-Nagaizumi, Shizuoka 411-8777, Japan. Tel: +81 559895222, Fax: +81 559895551,e-mail: yu.okamura@ scchr.jp

Key Words: Hepatocellular carcinoma, CYP3A4 gene, downregulation, overall survival, early recurrence. regulation of CYP3A4 gene $(p=0.019)$ as independent predictors for early recurrence. Conclusion: CYP3A4 was identified as a novel tumor suppressor gene related to a poor prognosis in $\mathrm{HCC}$.

Hepatocellular carcinoma (HCC) is the fifth leading cause of cancer-related death worldwide (1). Etiological factors of HCC include $\mathrm{HBV}, \mathrm{HCV}$, excess alcohol consumption, metabolic diseases, and specific carcinogen exposure. Therefore, the process of liver carcinogenesis is heterogeneous, and HCCs usually develop in the setting of chronic inflammation of the liver associated with a genomic mutation. The mechanism of liver carcinogenesis involves a unique combination of somatic alterations including genetic, epigenetic, transcriptomic and metabolic changes that form its unique molecular fingerprint (2). Thus, elucidating the molecular mechanisms and developing novel biomarkers are important for the early detection of HCC and improved outcomes $(3,4)$.

Recently, results of whole-genome sequencing analyses have shown that mutations in TP53, CTNNB1, AXIN1, ARIDIA, ARID2 and BRD7 occur in $60 \%$ of patients with HCC (5-8). However, many microarray studies of HCC have shown quite different results, as each study focused on a somewhat different point (9-11).

Project HOPE (High-tech Omics-based Patient Evaluation) began from 2014 using integrated gene expression profiling (GEP) of each cancer tissue as well as diathesis of each patient, who receive operations at Shizuoka Cancer Center Hospital (12). The aim of this study was to identify novel genes displaying altered gene expression related to survival and early recurrence after hepatectomy for HCC using the results of the GEP analysis. 


\section{Materials and Methods}

Subjects. Surgically-resected tumor specimens were obtained from 92 consecutive patients who underwent curative resection for HCC at the Division of Hepato-Biliary-Pancreatic Surgery of Shizuoka Cancer Center Hospital between January 2014 and October 2016 and had enrolled in Project HOPE. All pathological slides of specimens from those patients were reviewed. Clinical and pathological data were collected from our prospectively recorded database. The tumor stage was assessed based on the seventh edition of the Union for International Cancer Control (UICC) classification (13). Early recurrence was defined as recurrence within six months after hepatectomy.

Ethical approval for all experimental protocols and study was obtained from the institutional review board at the Shizuoka Cancer Center (Authorization Number: 25-33). Written informed consent was obtained from all patients enrolled in the study. All experiments using clinical samples were carried out in accordance with the approved guidelines.

Clinical samples. Tumor tissue samples with sizes corresponding to weights of $\geq 0.1 \mathrm{~g}$ were dissected from resected specimens, along with samples of surrounding normal tissue. The areas from which tumor samples were dissected were visually assessed as containing $\geq 50 \%$ tumor content. For the RNA analysis, tissue samples were submerged in RNAlater solution (Thermo Fisher Scientific, Waltham, MA, USA), minced, and stored at $4^{\circ} \mathrm{C}$ before RNA extraction.

RNA isolation. Total RNA was extracted from approximately $10 \mathrm{mg}$ of minced tissue samples using the miRNeasy Mini Kit (Qiagen, Hilden, Germany) as described previously (14). RNA samples with RNA integrity number $\geq 6.0$ was used for microarray analysis.

Gene expression profiling (GEP) analysis. RNA samples with RNA integrity number $\geq 6.0$ were used for the microarray analysis. Microarray analysis was performed as described previously (14). Briefly, total RNA (100 ng) was fluorescence-labeled and hybridized to the SurePrint G3 Human Gene Expression 8×60 K v2 Microarray (Agilent Technologies, Santa Clara, CA, USA). Microarray analysis was performed in accordance with the MIAME guidelines (15). Data analysis was performed using GeneSpring GX software (Agilent Technologies) and Microsoft Excel. Raw signal intensity values were $\log$ transformed and normalized to the 75th percentile. The fold change between tumor and non-tumor tissues from the same patient was calculated using the normalized intensity values. Probes expressed at raw signal values $<10$ in both tumor and non-tumor tissues were excluded from further analysis.

Reverse transcription polymerase chain reaction (RT-PCR) for $m R N A$ analysis. Quantitative mRNA levels were determined using real-time RT-PCR with the Applied Biosystems 7900 HT Sequence Detection System (Applied Biosystems), a TaqMan Gene Expression assay for human CYP3A4 (assay ID Hs02514989; Applied Biosystems), and a Eukaryotic 18S rRNA Endogenous Control (Applied Biosystems) as an endogenous control. cDNA was generated using $100 \mathrm{ng}$ of the total RNA and a High-capacity cDNA Reverse Transcription Kit (Applied Biosystems). RT-PCR was carried out in a total volume of $20 \mu \mathrm{l}$ using $100 \mathrm{ng}$ of cDNA, TaqMan Fast Advanced Master Mix (Applied Biosystems), and the respective TaqMan reagents for target genes. The conditions for amplification were $95^{\circ} \mathrm{C}$ for $20 \mathrm{~s}$ followed by 40 cycles at $95^{\circ} \mathrm{C}$ for
Table I. Patients demographics $(n=92)$.

\begin{tabular}{lc}
\hline Age (years) & $71(42-87)$ \\
Gender (male/female) & $73 / 19$ \\
Etiology of liver disease (viral/non-viral) & $46 / 46$ \\
HBsAg-positive (\%) & $15(16)$ \\
Anti-HCV Ab-positive (\%) & $31(34)$ \\
AFP (ng/mL) & $12.0(1.3-198,061)$ \\
DCP (mAU/mL) & $519(13-446,000)$ \\
Size (mm) & $43(9-180)$ \\
Tumor number (solitary/multiple) & $72 / 20$ \\
Microscopic portal invasion (present) & $23(25)$ \\
Microscopic venous invasion (present) & $22(24)$ \\
Microsatellite lesions (present) & $18(20)$ \\
UICC stage (I/II+III) & $46 / 46$ \\
Follow up duration (months) & $19.4(1.2-33.7)$ \\
\hline
\end{tabular}

HBsAg, Hepatitis B surface antigen; HCV, hepatitis C virus; Ab, antibody; AFP, alpha-fetoprotein; DCP, des-gamma-carboxy prothrombin. The values in parentheses are percentages unless otherwise indicated. "The value indicates the median (range).

$1 \mathrm{~s}$ and $60^{\circ} \mathrm{C}$ for $20 \mathrm{~s}$. Samples were analyzed in triplicate as biological replicates. The levels of CYP3A4 mRNA were defined from the cycle threshold $(\mathrm{Ct})$. $\mathrm{Ct}$ were normalized with reference to the level of 18S rRNA in each sample using the comparative $\mathrm{Ct}$ method, and $\triangle \mathrm{Ct}$ was defined as the difference in threshold cycles for CYP3A4 mRNA and 18S rRNA (16).

Immunohistochemical (IHC) analysis. All resected specimens were fixed in $10 \%$ formalin, dehydrated and embedded in paraffin. Paraffin sections of $3-\mu \mathrm{m}$ thickness containing representative histology of the tumor were used for the IHC analysis. IHC was performed using the Bond III automated stainer and BOND Polymer Refine Detection kit (Leica Biosystems). The sections were pretreated with epitope retrieval BOND1 for $20 \mathrm{~min}$ at $100^{\circ} \mathrm{C}$ and then reacted with anti-CYP450 3A4 rabbit polyclonal antibody at 1:100 dilution (ab3572, Abcam). After reaction with diaminobenzidine chromogen, the sections were counterstained with hematoxylin, and the stained sections were independently evaluated by two investigators (R.A. and Y.K).

Statistical analyses. The categorical variables were compared using the chi-squared test or Fisher's exact test, as appropriate. Continuous variables were compared using the Mann-Whitney $U$-test. The cumulative overall survival (OS) curve was analyzed using the Kaplan-Meier method and compared using the log-rank test. A Cox proportional hazards model was used for the univariate and multivariate analyses, and all factors found to be significant predictors of the OS $(p<0.10)$ in the univariate analysis were entered into the multivariate analysis. The multivariate analysis was performed via the logistic regression method using a backward stepwise selection model. All statistical analyses were performed using the SPSS 24.0 software package (SPSS, Inc., Chicago, IL, USA), and $p$-values of $<0.05$ in 2-tailed tests were considered to be significant.

\section{Results}

Patient characteristics. The patient characteristics are shown in Table I. The rate of patients with hepatitis B surface antigen was 


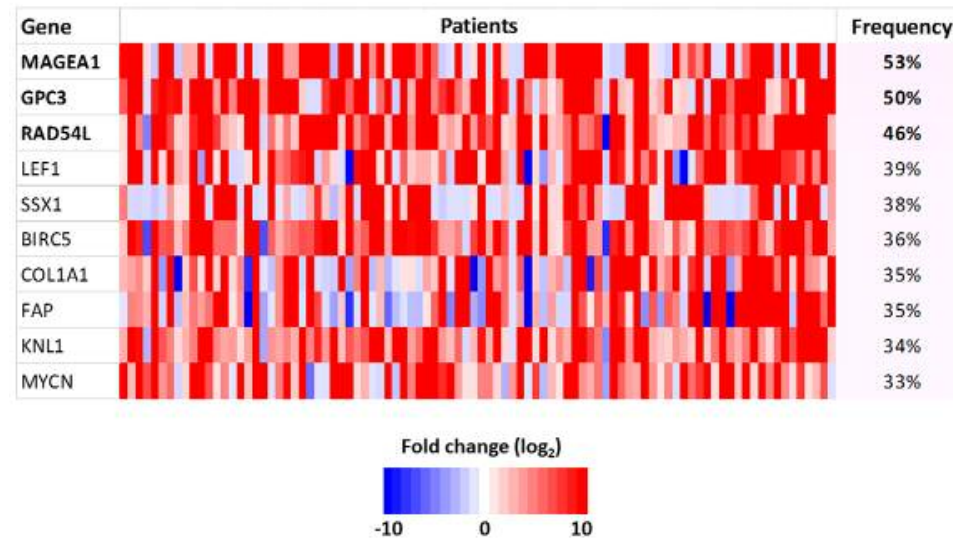

Figure 1. Results of GEP using a microarray analysis. Genes that were frequently up-regulated in tumor tissue compared to non-tumor tissue.

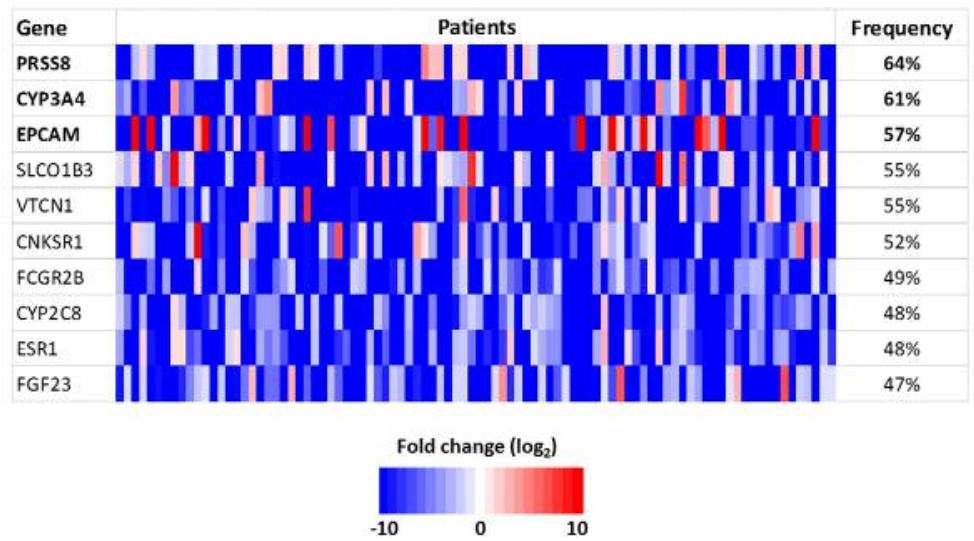

Figure 2. Results of GEP using a microarray analysis. Genes that were frequently down-regulated in tumor tissue compared to non-tumor tissue.

$17 \%$, and the rate of patients with anti-hepatitis $\mathrm{C}$ virus antibody was $34 \%$. The median follow-up duration was 19.4 months.

GEP analyses. We first identified genes showing aberrant expression in HCC. To extract genes, we narrowed down to 820 cancer-related genes (SCC-820) (14) in order to focus on genes with oncogenic characteristics. Genes with aberrant expression were selected by the difference of expression levels with $\geq 10$-fold change between tumor and non-tumor tissues. As a result, the top three up-regulated genes in tumor tissue were found to be MAGEAl in 49 patients $(53 \%)$, GPC3 in 46 patients $(50 \%)$ and RAD54L in 42 patients (46\%) among SCC-820 genes (Figure 1). The top three down-regulated genes in tumor tissue were found to be PRSS8 in 59 patients (64\%), CYP3A4 in 56 patients $(61 \%)$ and EPCAM in 52 patients (57\%) (Figure 2). We used these six genes as candidate novel biomarkers for predicting the prognosis in patients with HCC.
Prognostic factors for overall survival. In the univariate analysis, a maximum tumor diameter $\geq 74 \mathrm{~mm}(p=0.037)$, UICC stage $\geq \mathrm{II}(p=0.005)$ and down-regulation of the CYP3A4 gene ( $p=0.041$, Figure 3A) were significant predictors for the OS. The multivariate analysis to identify novel biomarkers revealed that UICC stage $\geq$ II (hazard ratio $[\mathrm{HR}]=40.0,95 \%$ confidence interval $[\mathrm{CI}] 2.65-500 p=0.008)$ and down-regulation of the CYP3A4 gene $(\mathrm{HR}=21.795 \% \mathrm{CI}=1.23-333 p=0.036)$ were independent predictors for the OS (Table II).

Predictors for early recurrence. Although there was no significant difference in the recurrence-free survival (RFS) according to the expression status of the $C Y P 3 A 4$ gene, the slope of the survival curve in the patients with downregulation of the $C Y P 3 A 4$ gene markedly decreased within 6 months postoperatively compared with the survival curve in the patients with not down-regulation of the CYP3A4 gene (Figure 4, $p=0.221$ ). We therefore investigated the 
A

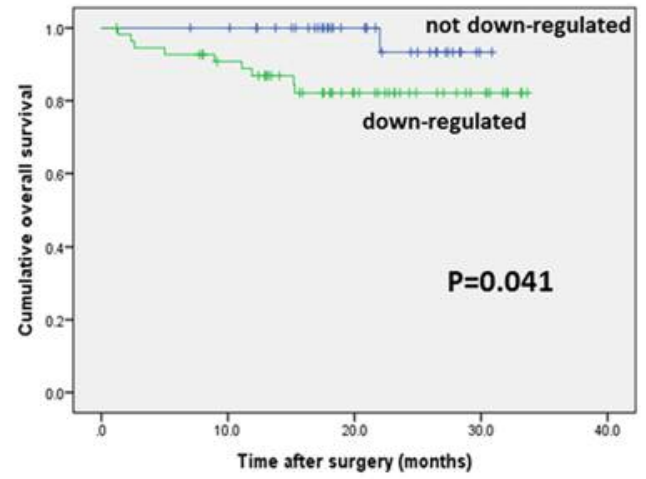

B

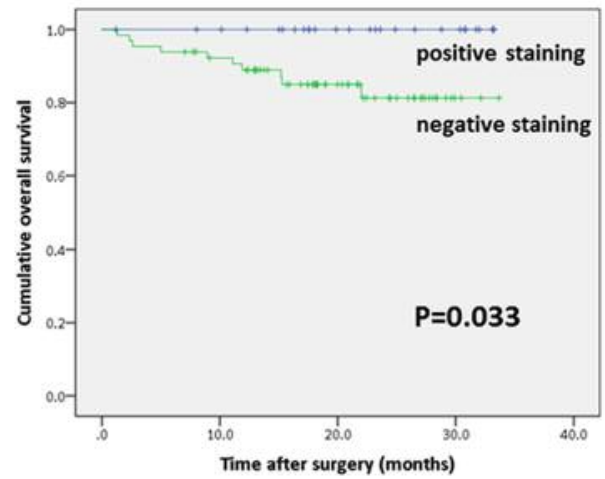

Figure 3. Survival curves of patients who underwent hepatectomy using the Kaplan-Meier method. A. Overall survival curve according to the CYP3A4 gene expression in a microarray analysis. B. Overall survival curve according to the IHC staining status of CYP3A4 protein.

associations between the expression of the CYP3A4 gene and early recurrence. In the univariate analysis, des-gammacarboxy prothrombin $<62(p=0.018)$, a maximum tumor diameter $\geq 74 \mathrm{~mm}(p=0.001)$, the presence of microscopic portal invasion $(p=0.006)$, the presence of microscopic venous invasion $(p=0.024)$, the presence of intrahepaticmetastasis $(p=0.029)$, UICC stage $\geq \mathrm{II}(p=0.022)$ and the down-regulation of the CYP3A4 gene $(p=0.004)$ were significant predictors for early recurrence. A multivariate analysis identified a maximum tumor diameter $>74 \mathrm{~mm}$ (odds ratio $[\mathrm{OR}] 6.10,95 \% \mathrm{CI}=1.60-23.26, p=0.008$ ), the presence of intrahepatic-metastasis $(\mathrm{OR}=6.02,95 \% \mathrm{CI}=1.32$ $27.78 p=0.020)$, and the decreased expression of the CYP3A4 gene $(\mathrm{OR}=15.87,95 \% \mathrm{CI}=1.59-166.67 p=0.019)$ as independent predictors for early recurrence (Table III).

A comparison of the clinicopathological factors according to the CYP3A4 gene expression. The frequency of welldifferentiated HCC in the patients with down-regulation of the $C Y P 3 A 4$ gene was significantly lower than in the patients with normal expression of the CYP3A4 gene (10.7\% vs. $30.6 \%, p=0.017$ ), but there were no significant differences between the two groups in other clinicopathological factors.

Association between the expression of the CYP3A4 gene in a microarray analysis and RT-PCR of tumor tissue. To verify the results of GEP, we evaluated the association between the expression of the CYP3A4 gene in the microarray analysis and those in RT-PCR of the tumor tissue using Spearman's correlation coefficient, significantly high correlations were found ( $p<0.001$, Figure 5A).

Association between IHC of CYP3A4 protein and the expression of the CYP3A4 gene in a microarray analysis of

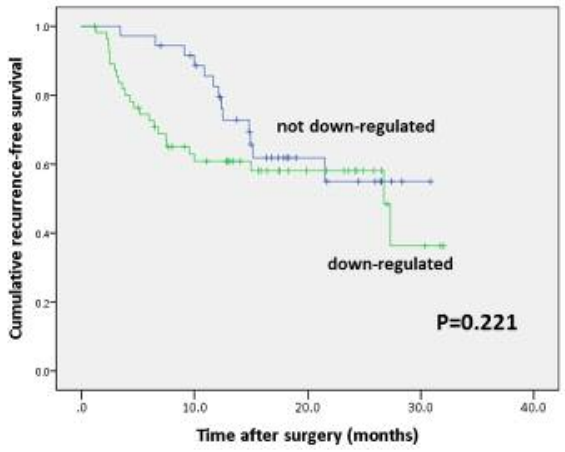

Figure 4. Recurrence-free survival curve according to the CYP3A4 gene expression in a microarray analysis. There were no significant differences in the recurrence-free survival according to the expression status of CYP3A4 gene. The slope of the survival curve in the patients with down-regulation of the CYP3A4 gene markedly decreased within 6 months postoperatively compared to the survival curve in the patients with not down-regulation of the CYP3A4 gene.

tumor tissue. In the IHC analysis, $C Y P 3 A 4$ protein was stained in the cytoplasm of tumor cells (Figure 6A). Figure 6B shows negative staining of tumor cells in the IHC analysis. In an analysis of the association between IHC of CYP3A4 protein and the expression of the CYP3A4 gene in a microarray analysis of tumor tissue using Spearman's correlation coefficient, significant correlations were found between these two factors (Figure 5B, $p<0.001$ ).

The optimal cut-off value of staining for CYP3A4 protein for dividing patients into two groups based on the greatest difference in overall survival (OS) was $30 \%$ when using the minimum $p$-value approach. The staining for CYP3A4 protein were classified according to the percentage of positive cells: staining in $>30 \%$ of tumor cells was regarded as positive and 
Table II. Prognostic factors for overall survival by univariate and multivariate analysis.

\begin{tabular}{|c|c|c|c|c|c|}
\hline & \multirow{2}{*}{$\begin{array}{c}\text { Number of } \\
\text { patients }\end{array}$} & \multirow{2}{*}{$\begin{array}{c}2 \text {-years } \\
\text { survival }(\%)\end{array}$} & \multirow{2}{*}{$\begin{array}{c}\text { Univariate } \\
\text { analysis } \\
p \text {-Value }\end{array}$} & \multicolumn{2}{|c|}{ Multivariate analysis } \\
\hline & & & & Hazard ratio (95\% Confidence interval) & $p$-Value \\
\hline AFP & & & 0.822 & & \\
\hline$<7$ & 37 & 87.2 & & & \\
\hline$\geq 7$ & 55 & 88.1 & & & \\
\hline DCP & & & 0.096 & & \\
\hline$<62$ & 26 & 79.7 & & & \\
\hline$\geq 62$ & 66 & 89.9 & & & \\
\hline Etiology of liver disease & & & 0.852 & & \\
\hline Viral & 46 & 88.6 & & & \\
\hline Non-viral & 46 & 85.8 & & & \\
\hline Histologic differentiation & & & 0.470 & & \\
\hline Well & 17 & 93.8 & & & \\
\hline Others & 75 & 85.5 & & & \\
\hline Size & & & 0.037 & & \\
\hline$<74 \mathrm{~mm}$ & 64 & 92.6 & & & \\
\hline$\geq 74 \mathrm{~mm}$ & 28 & 81.4 & & & \\
\hline Tumor number & & & 0.415 & & \\
\hline Solitary & 72 & 87.9 & & & \\
\hline Multiple & 20 & 84.2 & & & \\
\hline Microscopic portal invasion & & & 0.205 & & \\
\hline Absent & 69 & 89.2 & & & \\
\hline Present & 23 & 80.1 & & & \\
\hline Microscopic venous invasion & & & 0.208 & & \\
\hline Absent & 70 & 89.2 & & & \\
\hline Present & 22 & 80.4 & & & \\
\hline Microsatellite lesions & & & 0.371 & & \\
\hline Absent & 74 & 89.3 & & & \\
\hline Present & 18 & 70.6 & & & \\
\hline Tumor stage & & & 0.005 & & 0.008 \\
\hline I & 46 & 95.7 & & 1 & \\
\hline II+III & 46 & 78.4 & & $40.0(2.65-500)$ & \\
\hline MAGEAl gene & & & 0.327 & & \\
\hline Up-regulated & 49 & 84.6 & & & \\
\hline Not up-regulated & 43 & 89.0 & & & \\
\hline$G P C 3$ gene & & & 0.437 & & \\
\hline Up-regulated & 46 & 85.3 & & & \\
\hline Not up-regulated & 46 & 88.6 & & & \\
\hline RAD54L gene & & & 0.713 & & \\
\hline Up-regulated & 42 & 90.2 & & & \\
\hline Not up-regulated & 50 & 84.0 & & & \\
\hline PRSS8 gene & & & 0.860 & & \\
\hline Not-down-regulated & 33 & 87.1 & & & \\
\hline Down-regulated & 59 & 86.3 & & & \\
\hline СYP3A4 gene & & & 0.041 & & 0.036 \\
\hline Down-regulated & 56 & 82.2 & & $21.7(1.23-333)$ & \\
\hline Not-down-regulated & 36 & 93.3 & & 1 & \\
\hline EPCAM gene & & & 0.882 & & \\
\hline Down-regulated & 52 & 85.8 & & & \\
\hline Not-down-regulated & 40 & 89.0 & & & \\
\hline
\end{tabular}

AFP, Alpha-fetoprotein; DCP, des-gamma-carboxy prothrombin; MAGEA1, melanoma-associated antigen 1; GPC3, glypican 3; RAD54L, RAD54-like (S. cerevisiae); PRSS8, protease, serine, 8; CYP3A4, cytochrome P450, family 3, subfamily A, polypeptide 4; EPCAM, epithelial cell adhesion molecule.

in $<30 \%$ of cells as negative. The cumulative OS rate in patients with negative staining of CYP3A4 protein was significantly poorer than in patients with positive staining of CYP3A4 (Figure 3B, $p=0.033$ ).

\section{Discussion}

In the present study, we performed an integrated analysis of GEP for patients with $\mathrm{HCC}$, and identified genes that were 
Table III. Univariate and multivariate analysis of factors predicting early recurrence.

\begin{tabular}{|c|c|c|c|c|c|}
\hline & \multicolumn{3}{|c|}{ Univariate analysis } & \multicolumn{2}{|c|}{ Multivariate analysis } \\
\hline & $\begin{array}{l}\text { Early recurrence }+ \\
\qquad(\mathrm{n}=15)\end{array}$ & $\begin{array}{l}\text { Early recurrence - } \\
\qquad(\mathrm{n}=77)\end{array}$ & $p$-Value & $\begin{array}{c}\text { Odds ratio } \\
\text { (95\% Confidence interval) }\end{array}$ & $p$-Value \\
\hline \multicolumn{6}{|l|}{ AFP } \\
\hline$<7$ & $9(60 \%)$ & $28(36 \%)$ & 0.088 & & \\
\hline$\geq 7$ & $6(40 \%)$ & $49(64 \%)$ & & & \\
\hline \multicolumn{6}{|l|}{ DCP } \\
\hline$<62$ & $8(53 \%)$ & $18(23 \%)$ & 0.018 & & \\
\hline$\geq 62$ & $7(47 \%)$ & $59(77 \%)$ & & & \\
\hline \multicolumn{6}{|l|}{ Etiology of liver disease } \\
\hline Viral & $9(60 \%)$ & $37(48 \%)$ & 0.147 & & \\
\hline Non-viral & $6(40 \%)$ & $40(52 \%)$ & & & \\
\hline \multicolumn{6}{|l|}{ Histologic differentiation } \\
\hline Well & $1(7 \%)$ & $16(21 \%)$ & 0.258 & & \\
\hline Others & $14(93 \%)$ & $61(79 \%)$ & & & \\
\hline \multicolumn{6}{|l|}{ Tumor diameter } \\
\hline$<74 \mathrm{~mm}$ & $5(33 \%)$ & $59(77 \%)$ & 0.001 & 1 & 0.008 \\
\hline$\geq 74 \mathrm{~mm}$ & $10(67 \%)$ & $18(23 \%)$ & & $6.10(1.60-23.26)$ & \\
\hline \multicolumn{6}{|l|}{ Tumor number } \\
\hline Solitary & $9(60 \%)$ & $63(82 \%)$ & 0.085 & & \\
\hline Multiple & $6(40 \%)$ & $14(18 \%)$ & & & \\
\hline \multicolumn{6}{|c|}{ Microscopic portal invasion } \\
\hline Absent & $7(47 \%)$ & $62(80 \%)$ & 0.006 & & \\
\hline Present & $8(53 \%)$ & $15(20 \%)$ & & & \\
\hline \multicolumn{6}{|c|}{ Microscopic venous invasion } \\
\hline Absent & $8(53 \%)$ & $62(80 \%)$ & 0.024 & & \\
\hline Present & $7(47 \%)$ & $15(20 \%)$ & & & \\
\hline \multicolumn{6}{|l|}{ Microsatellite lesions } \\
\hline Absent & $9(60 \%)$ & $65(84 \%)$ & 0.029 & 1 & 0.020 \\
\hline Present & $6(4 \%)$ & $12(16 \%)$ & & $6.02(1.32-27.78)$ & \\
\hline \multicolumn{6}{|l|}{ Tumor stage } \\
\hline I & $3(20 \%)$ & $43(56 \%)$ & 0.022 & & \\
\hline II+III & $12(80 \%)$ & $34(44 \%)$ & & & \\
\hline \multicolumn{6}{|l|}{$M A G E A l$ gene } \\
\hline Not up-regulated & $7(47 \%)$ & $36(47 \%)$ & 0.995 & & \\
\hline Up-regulated & $8(53 \%)$ & $41(53 \%)$ & & & \\
\hline \multicolumn{6}{|l|}{ GPC 3 gene } \\
\hline Not up-regulated & $7(47 \%)$ & $39(51 \%)$ & 0.778 & & \\
\hline Up-regulated & $8(53 \%)$ & $38(49 \%)$ & & & \\
\hline \multicolumn{6}{|l|}{$R A D 54 L$ gene } \\
\hline Not up-regulated & $8(53 \%)$ & $42(54 \%)$ & 0.931 & & \\
\hline Up-regulated & $7(47 \%)$ & $35(46 \%)$ & & & \\
\hline \multicolumn{6}{|l|}{ PRSS8 gene } \\
\hline Not-down-regulated & $3(20 \%)$ & $30(39 \%)$ & 0.241 & & \\
\hline Down-regulated & $12(80 \%)$ & $47(61 \%)$ & & & \\
\hline \multicolumn{6}{|l|}{ CYP3A4 gene } \\
\hline Not-down-regulated & $1(7 \%)$ & $35(45 \%)$ & 0.004 & 1 & 0.019 \\
\hline Down-regulated & $14(93 \%)$ & $42(55 \%)$ & & $15.87(1.59-166.67)$ & \\
\hline \multicolumn{6}{|l|}{$E P C A M$ gene } \\
\hline Not-down-regulated & $9(60 \%)$ & $31(60 \%$ & 0.158 & & \\
\hline Down-regulated & $6(40 \%)$ & $46(60 \%)$ & & & \\
\hline
\end{tabular}

AFP, Alpha-fetoprotein; DCP, des-gamma-carboxy prothrombin; MAGEA1, melanoma-associated antigen 1; GPC3, glypican 3; RAD54L, RAD54-like (S. cerevisiae); PRSS8, protease, serine, 8; CYP3A4, cytochrome P450, family 3, subfamily A, polypeptide 4; EPCAM, epithelial cell adhesion molecule.

frequently up- or down-regulated in tumor tissue compared with non-tumor tissue using a microarray analysis. We analyzed the relationship between the expression of candidate genes and the prognosis and found that down-regulation of the CYP3A4 gene was an independent predictor for the survival and early recurrence. To verify the results of the microarray analysis, we performed RT-PCR and IHC. Both RT-PCR and IHC correlated with the findings of the 
A

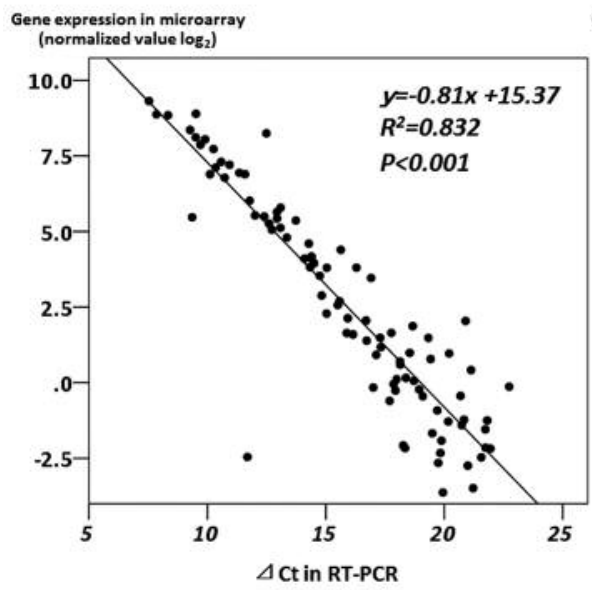

B

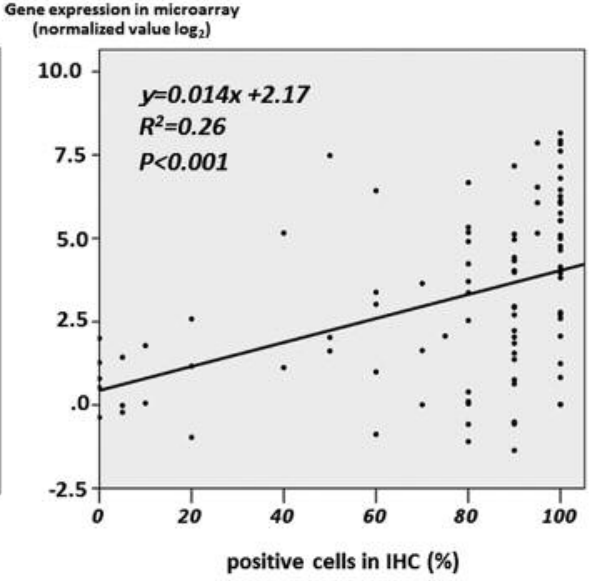

Figure 5. A: Correlation analysis between the expression of the CYP3A4 gene in a microarray analysis and by RT-PCR of tumor tissue. B: Correlation analysis between the IHC staining of CYP3A4 protein and the expression of CYP3A4 gene in a microarray analysis of tumor tissue.

A

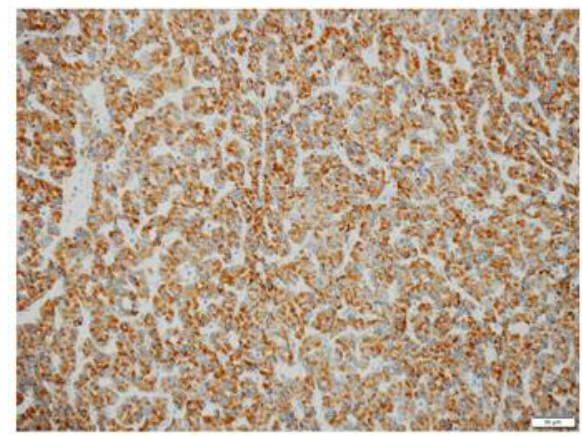

B

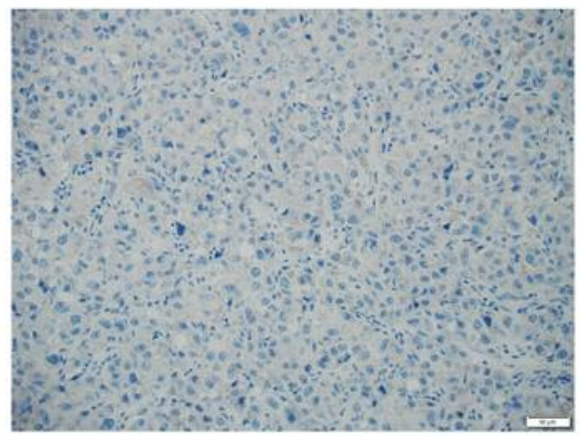

Figure 6. A: IHC analysis of CYP3A4 in tumor tissue, that showed positive staining in the cytoplasm. B: IHC analysis of CYP3A4 in tumor tissue, which showed negative staining.

microarray analysis, and we identified $C Y P 3 A 4$ as a novel, potential clinically useful biomarker for the prognosis of HCC. Although many reports have performed comprehensive microarray analyses of the GEP for patients with HCC (10, 17-24), the frequency of down-regulation and the prognostic impact of the CYP3A4 gene have not yet described in any reports of integrated microarray analyses. Most of these reports have instead focused on genes related to cancer pathways, and few have focused on the frequency of aberrant gene expression and their impact on the prognosis. The present study is the first report to describe the frequency of down-regulation of the CYP3A4 gene and its prognostic impact for the OS and early recurrence.

CYP3A4 is mainly expressed in the liver and intestine, and its enzymes are involved in the metabolism of about $50 \%$ of all drugs, participating in the metabolic activation and metabolism of several pre-carcinogens (25-27). Ba et al. reported that benzo[a]pyrene, which is metabolized by CYP3A4, promoted HCC metastasis and progression in vitro and in mouse models. They also indicated that the survival curves of benzo[a]pyrene-exposed HCC-bearing mice was significantly poor (28). Although similar results have not been obtained in human HCC tissue, the down-regulation of CYP3A4 might be associated with a lower metabolism of pre-carcinogens, which leads to higher exposure of precarcinogens. As a result, carcinogenesis easily occurs in patients with down-regulation of the CYP3A4 gene.

Furthermore, the present study showed that tumor differentiation is more aggressive in patients with downregulation of the $C Y P 3 A 4$ gene than in those with normal expression. Many papers have reported an association between tumor differentiation and a poor prognosis, and this 
finding might be related to the poor prognosis of patients with down-regulation of the CYP3A4 gene (29). For these reasons, down regulation of the CYP $3 A 4$ gene might be associated with aggressive tumor behaviors, thereby leading to a higher rate of early recurrence and a poorer OS. The lack of a significant difference in the RFS according to the CYP3A4 gene expression despite these findings might be due to the follow-up duration being too short.

The present study revealed high correlation between the expression of the CYP3A4 gene in microarray analyses and in RT-PCR, suggesting that the GEP using the microarray had been compiled accurately and the CYP $3 A 4$ gene was a potential novel biomarker for the prognosis of HCC. However, microarray analyses and RT-PCR are difficult to perform in daily clinical practice. The present study therefore confirmed the expression of CYP3A4 protein using IHC. Evaluating the IHC status of CYP3A4 protein may be a useful novel biomarker for predicting the prognosis in daily clinical practice. Although an appropriate adjuvant chemotherapy regimen for HCC has not yet been established, such therapy may be beneficial for patients with negative staining of CYP3A4 protein, as these patients may have potential residual cancer. Improving the prognosis of HCC will require proper identification of patients who may benefit from adjuvant chemotherapy for HCC.

Regarding the mechanisms underlying the downregulation of the CYP $3 A 4$ gene, the expression of the CYP3A4 gene was regulated by nuclear receptors, wellestablished xenobiotic sensors capable of binding to various structurally diverse chemicals, such as pregnane $\mathrm{X}$ receptor (PXR) (30) and constitutive androstane receptor (CAR) (30, 31). Promoter hyper-methylation has been reported to result in repression of CAR and PXR expression, which induces the down-regulation of drug-metabolizing enzymes, including the CYP3A4 gene, in human pluripotent stem cellderived hepatocyte-like cells (32). CpG methylation of the CYP3A4 promoter was also reported to induce the downregulation of the CYP3A4 gene in human non-cancerous liver and human hepatoma cell lines $(33,34)$. Although the precise mechanisms underlying the down-regulation of the CYP3A4 gene were not elucidated in human HCC tissue, several mechanisms, such as promoter hyper-methylation of CYP3A4, CAR and PXR, might repress the expression of the CYP3A4 gene.

There are several limitations associated with the present study. First, the follow-up duration of the present study was slightly short. Second, this study was conducted at a single center, and the number of patients was slightly small. Further prospective multi-institutional studies are, therefore, needed to validate the results of the present study objectively.

In conclusion, the down-regulation of the CYP $3 A 4$ gene and protein were correlated with a poor prognosis in HCC.

\section{Acknowledgements}

The Authors thank Koji Muramatsu and Yuko Watanabe for their valuable technical assistance.

\section{References}

1 Siegel R, Naishadham D and Jemal A: Cancer statistics, 2013. CA Cancer J Clin 63: 11-30, 2013.

2 Marquardt JU, Andersen JB and Thorgeirsson SS: Functional and genetic deconstruction of the cellular origin in liver cancer. Nat Rev Cancer 15: 653-667, 2015.

3 Gentile I, Buonomo AR, Scotto R, Zappulo E, Carriero C, Piccirillo M, Izzo F, Rizzo M, Cerasuolo D, Borgia G and Cavalcanti E: Diagnostic accuracy of pivka-ii, alpha-fetoprotein and a combination of both in diagnosis of hepatocellular carcinoma in patients affected by chronic hev infection. In Vivo 31: 695-700, 2017.

4 Cioca A, Cimpean AM, Ceausu RA, Tarlui V, Toma A, Marin I and Raica M: Evaluation of podoplanin expression in hepatocellular carcinoma using RNAscope and immunohisto-chemistry - a preliminary report. Cancer Genomics Proteomics 14: 383-387, 2017.

5 Schulze K, Imbeaud S, Letouze E, Alexandrov LB, Calderaro J, Rebouissou S, Couchy G, Meiller C, Shinde J, Soysouvanh F, Calatayud AL, Pinyol R, Pelletier L, Balabaud C, Laurent A, Blanc JF, Mazzaferro V, Calvo F, Villanueva A, Nault JC, Bioulac-Sage $\mathrm{P}$, Stratton MR, Llovet JM and Zucman-Rossi J: Exome sequencing of hepatocellular carcinomas identifies new mutational signatures and potential therapeutic targets. Nat Genet 47: 505-511, 2015.

6 Fujimoto A, Furuta M, Totoki Y, Tsunoda T, Kato M, Shiraishi Y, Tanaka H, Taniguchi H, Kawakami Y, Ueno M, Gotoh K, Ariizumi S, Wardell CP, Hayami S, Nakamura T, Aikata H, Arihiro K, Boroevich KA, Abe T, Nakano K, Maejima K, SasakiOku A, Ohsawa A, Shibuya T, Nakamura H, Hama N, Hosoda F, Arai Y, Ohashi S, Urushidate T, Nagae G, Yamamoto S, Ueda H, Tatsuno K, Ojima H, Hiraoka N, Okusaka T, Kubo M, Marubashi S, Yamada T, Hirano S, Yamamoto M, Ohdan H, Shimada K, Ishikawa O, Yamaue H, Chayama K, Miyano S, Aburatani H, Shibata T and Nakagawa H: Whole-genome mutational landscape and characterization of noncoding and structural mutations in liver cancer. Nat Genet 48: 500-509, 2016.

7 Totoki Y, Tatsuno K, Covington KR, Ueda H, Creighton CJ, Kato M, Tsuji S, Donehower LA, Slagle BL, Nakamura H, Yamamoto S, Shinbrot E, Hama N, Lehmkuhl M, Hosoda F, Arai Y, Walker K, Dahdouli M, Gotoh K, Nagae G, Gingras MC, Muzny DM, Ojima H, Shimada K, Midorikawa Y, Goss JA, Cotton R, Hayashi A, Shibahara J, Ishikawa S, Guiteau J, Tanaka M, Urushidate T, Ohashi S, Okada N, Doddapaneni H, Wang M, Zhu Y, Dinh H, Okusaka T, Kokudo N, Kosuge T, Takayama T, Fukayama M, Gibbs RA, Wheeler DA, Aburatani H and Shibata T: Trans-ancestry mutational landscape of hepatocellular carcinoma genomes. Nat Genet 46: 1267-1273, 2014.

8 Meerzaman DM, Yan C, Chen QR, Edmonson MN, Schaefer CF, Clifford RJ, Dunn BK, Dong L, Finney RP, Cultraro CM, Hu Y, Yang Z, Nguyen CV, Kelley JM, Cai S, Zhang H, Zhang J, Wilson R, Messmer L, Chung YH, Kim JA, Park NH, Lyu MS, Song IH, Komatsoulis $\mathrm{G}$ and Buetow KH: Genome-wide transcriptional sequencing identifies novel mutations in metabolic genes in human hepatocellular carcinoma. Cancer Genomics Proteomics 11: 1-12, 2014. 
9 Villa E, Critelli R, Lei B, Marzocchi G, Camma C, Giannelli G, Pontisso P, Cabibbo G, Enea M, Colopi S, Caporali C, Pollicino T, Milosa F, Karampatou A, Todesca P, Bertolini E, Maccio L, Martinez-Chantar ML, Turola E, Del Buono M, De Maria N, Ballestri S, Schepis F, Loria P, Enrico Gerunda G, Losi L and Cillo U: Neoangiogenesis-related genes are hallmarks of fastgrowing hepatocellular carcinomas and worst survival. Results from a prospective study. Gut 65: 861-869, 2016.

10 Wang F, Wang R, Li Q, Qu X, Hao Y, Yang J, Zhao H, Wang Q, Li G, Zhang F, Zhang H, Zhou X, Peng X, Bian Y and Xiao W: A transcriptome profile in hepatocellular carcinomas based on integrated analysis of microarray studies. Diagn Pathol 12: 4, 2017.

11 Sakabe T, Azumi J, Umekita Y, Toriguchi K, Hatano E, Hirooka Y and Shiota G: Expression of cancer stem cell-associated dkk1 mrna serves as prognostic marker for hepatocellular carcinoma. Anticancer Res 37: 4881-4888, 2017.

12 Yamaguchi K, Urakami K, Ohshima K, Mochizuki T, Akiyama Y, Uesaka K, Nakajima T, Takahashi M, Tamai S and Kusuhara M: Implementation of individualized medicine for cancer patients by multiomics-based analyses-the project hope. Biomed Res 35: 407-412, 2014.

13 Sobin L, Gospodarowicz M and Wittekind C: TNM classification of Malignant Tumours, 7th ed. Wiley-Liss: New York, 2009.

14 Ohshima K, Hatakeyama K, Nagashima T, Watanabe Y, Kanto K, Doi Y, Ide T, Shimoda Y, Tanabe T, Ohnami S, Ohnami S, Serizawa M, Maruyama K, Akiyama Y, Urakami K, Kusuhara M, Mochizuki T and Yamaguchi K: Integrated analysis of gene expression and copy number identified potential cancer driver genes with amplification-dependent overexpression in 1,454 solid tumors. Sci Rep 7: 641, 2017.

15 Brazma A, Hingamp P, Quackenbush J, Sherlock G, Spellman P, Stoeckert C, Aach J, Ansorge W, Ball CA, Causton HC, Gaasterland T, Glenisson P, Holstege FC, Kim IF, Markowitz V, Matese JC, Parkinson H, Robinson A, Sarkans U, SchulzeKremer S, Stewart J, Taylor R, Vilo J and Vingron M: Minimum information about a microarray experiment (miame)-toward standards for microarray data. Nat Genet 29: 365-371, 2001.

16 Livak KJ and Schmittgen TD: Analysis of relative gene expression data using real-time quantitative pcr and the 2(-delta delta $\mathrm{c}(\mathrm{t}))$ method. Methods 25: 402-408, 2001.

17 Bai Y, Xue Y, Xie X, Yu T, Zhu Y, Ge Q and Lu Z: The rna expression signature of the hepg 2 cell line as determined by the integrated analysis of mirna and mrna expression profiles. Gene 548: 91-100, 2014.

18 Yang H, Zhang X, Cai XY, Wen DY, Ye ZH, Liang L, Zhang L, Wang HL, Chen G and Feng ZB: From big data to diagnosis and prognosis: Gene expression signatures in liver hepatocellular carcinoma. PeerJ 5: e3089, 2017.

19 Hoshida Y, Nijman SM, Kobayashi M, Chan JA, Brunet JP, Chiang DY, Villanueva A, Newell P, Ikeda K, Hashimoto M, Watanabe G, Gabriel S, Friedman SL, Kumada H, Llovet JM and Golub TR: Integrative transcriptome analysis reveals common molecular subclasses of human hepatocellular carcinoma. Cancer Res 69: 7385-7392, 2009.

20 Chung EJ, Sung YK, Farooq M, Kim Y, Im S, Tak WY, Hwang YJ, Kim YI, Han HS, Kim JC and Kim MK: Gene expression profile analysis in human hepatocellular carcinoma by cdna microarray. Mol Cells 14: 382-387, 2002.

21 Budhu A, Roessler S, Zhao X, Yu Z, Forgues M, Ji J, Karoly E, Qin LX, Ye QH, Jia HL, Fan J, Sun HC, Tang ZY and Wang
XW: Integrated metabolite and gene expression profiles identify lipid biomarkers associated with progression of hepatocellular carcinoma and patient outcomes. Gastroenterology 144: 10661075,2013

22 Ramesh V and Ganesan K: Integrative analysis of transcriptome and mirnome unveils the key regulatory connections involved in different stages of hepatocellular carcinoma. Genes Cells 21: 949-965, 2016.

23 Cao Y, Agarwal R, Dituri F, Lupo L, Trerotoli P, Mancarella S, Winter P and Giannelli G: Ngs-based transcriptome profiling reveals biomarkers for companion diagnostics of the tgf-beta receptor blocker galunisertib in hcc. Cell Death Dis 8: e2634, 2017.

24 Chen J, Qian Z, Li F, Li J and Lu Y: Integrative analysis of microarray data to reveal regulation patterns in the pathogenesis of hepatocellular carcinoma. Gut Liver 11: 112-120, 2017.

25 Rodriguez-Antona $\mathrm{C}$ and Ingelman-Sundberg M: Cytochrome p450 pharmacogenetics and cancer. Oncogene 25: 1679-1691, 2006.

26 Ingelman-Sundberg M: Human drug metabolising cytochrome p450 enzymes: Properties and polymorphisms. Naunyn Schmiedebergs Arch Pharmacol 369: 89-104, 2004.

27 Kamdem LK, Meineke I, Godtel-Armbrust U, Brockmoller J and Wojnowski L: Dominant contribution of p450 3a4 to the hepatic carcinogenic activation of aflatoxin b1. Chem Res Toxicol 19: 577-586, 2006.

28 Ba Q, Li J, Huang C, Qiu H, Li J, Chu R, Zhang W, Xie D, Wu $\mathrm{Y}$ and Wang $\mathrm{H}$ : Effects of benzo[a]pyrene exposure on human hepatocellular carcinoma cell angiogenesis, metastasis, and nfkappab signaling. Environ Health Perspect 123: 246-254, 2015.

29 Adachi E, Maehara S, Tsujita E, Taguchi K, Aishima S, Rikimaru T, Yamashita Y and Tanaka S: Clinicopathologic risk factors for recurrence after a curative hepatic resection for hepatocellular carcinoma. Surgery 131: S148-152, 2002.

30 Wang YM, Ong SS, Chai SC and Chen T: Role of car and pxr in xenobiotic sensing and metabolism. Expert Opin Drug Metab Toxicol 8: 803-817, 2012.

31 Zhang L, Miao XJ, Wang X, Pan HH, Li P, Ren H, Jia YR, Lu C, Wang HB, Yuan L and Zhang GL: Antiproliferation of berberine is mediated by epigenetic modification of constitutive androstane receptor (car) metabolic pathway in hepatoma cells. Sci Rep 6: 28116, 2016.

32 Kim HM, Kim JW, Choi Y, Chun HS, Im I, Han YM, Song CW, Yoon S and Park HJ: Xeno-sensing activity of the aryl hydrocarbon receptor in human pluripotent stem cell-derived hepatocyte-like cells. Sci Rep 6: 21684, 2016.

33 Dannenberg LO and Edenberg HJ: Epigenetics of gene expression in human hepatoma cells: Expression profiling the response to inhibition of DNA methylation and histone deacetylation. BMC Genomics 7: 181, 2006.

34 Kacevska M, Ivanov M, Wyss A, Kasela S, Milani L, Rane A and Ingelman-Sundberg M: DNA methylation dynamics in the hepatic cyp3a4 gene promoter. Biochimie 94: 2338-2344, 2012.

Received September 5, 2017

Revised October 2, 2017

Accepted October 3, 2017 